\title{
Assessing Students' Perception Towards the Teaching of Sexuality Education in Senior Secondary Schools in Nigeria
}

\author{
Joy-Telu Hamilton-Ekeke*
}

Department of Science Education, Niger Delta University, Wilberforce Island, Bayelsa State, Nigeria

*Corresponding Author E-mail: joyhamilton@ndu.edu.ng; joytelu@yahoo.com

Received: 30 January 2019, Revised: 14 March 2019, Accepted: 17 March 2019

\begin{abstract}
The absence of systematic sex education in schools would seem to be a transfer from the tendency among parents to shy away from answering questions about sex and procreation which young people ask. The prevalence of indulgence in premarital sex or unsafe sexual behaviours by secondary school students who are mostly adolescents has attracted growing concerns from all stakeholders. These unsafe sexual behaviours may have significant unpleasant consequences on their health which they may not be necessarily aware of considering the high prevalence rate of sexually transmitted diseases. Over the years, there has been a heated debate on whether sexuality education should be included in school curriculum. While some think it is immoral for sex education to be included in the school curriculum, others strongly believe that the teaching of sex education is ideal for teenagers as it will guide them who early exposure to technology makes them vulnerable to misinformation. Parents on the other hand are worried about the way sexuality education is being taught in schools. Yet these divergent views represent both sides of the same coin - a genuine concern borne out of the need to protect and ensure the safety of the future of teenagers and young people in general. This study therefore looked at the students' perception of sexuality education taught to them in the school and how students' predominant views on sex influence their acceptance of sexuality education.
\end{abstract}

Key words: Sexuality education, Adolescents, Perception, Nigeria, Abstinence.

\section{Introduction}

Sexuality education is neither the exclusive preserve of parents in the home nor that of the teachers in the school. It is the responsibility of all who are charged with the upbringing of young people under their care or guidance. The call for holistic sex education is not new in our society and various demanding factors have prompted such a call. Among them are continued reports of incidence of sexrelated deviant behaviour such as rape, sterility of married youths as a result of damage done to reproductive system earlier in life, the termination of unwanted pregnancies resulting in death. Psychologist would attest to the fact that sexual behaviour begins at infancy. A renowned psychologist, (Barret, 2010) has postulated that problems associated with the development of sexual behaviour are frequently cited as responsible for adult personality difficulties. This is the reason the school should assume the responsibility of imparting a holistic and carefully designed sex education to adolescents in schools. The practical advantages are numerous. It is believed that the necessary awareness gained will help young people to prevent unintended pregnancies and even the urge to 
secretly terminate such pregnancy would be reduced. Sex education may promote total abstinence. To a large extent, it would put into check the spread of STDs among young people.

Children start questioning and learning about things very early; all of these early learning especially in the home is crucial to the healthy and emotional development of children. Both parents have huge roles to play in the education of their children, thus, (Akpama, 2013), stated that fathers should be responsible for teaching their sons, while mothers should teach their daughters in giving all those biological and effective information on sex-related matters.

(Fentahun et al., 2012) also noted that parents are the most important educators of their children in these matters, and hence they should be held responsible if this duty to their children is neglected. It, therefore, requires them (the parents) to make concerted efforts to be good examples, to listen to their children, to give them their time and to show that they can trust them. According to (Akande et al., 2007), sex education ought to be a fundamental right of every child and the duty of every responsible parent. Parents may think that the school should be responsible for both moral and sex education of their children. Yes the school has a role to play but the role of the school should be complimentary to the role of the family. Parents should know that the school can never replace them in the roles they ought to play as examples worth emulating.

Adolescence follows puberty and brings with it conflicts between parents and children because during this period, physical changes are often matched by new cognitive abilities and a great desire to achieve greater independence from the family unit. The society often times feels helpless and quite slow to cope with these fast changing adolescents. Today, the problems resulting from insufficient sexuality education as well as wrong perceptions prevalent among school students on sex issues are not only numerous but also pose grave consequences to their future and that of the Nation at large. These include problems ranging from high rate of involvement of young people in sexual promiscuity and prostitution, high incidents of sexually transmitted diseases among young people, and increased abortions due to unintended pregnancies and these have resulted in high rates of school dropouts. To this end, the study seeks to understand the perception of students on the teaching of sexuality education in senior secondary schools in Nigeria.

Four research questions are posited in the research:

To what extent will the teaching of the content of sex education influence students' perception of sexuality education?

Will teacher's gender influence students attitude to the teaching of sexuality education?

Is there a relationship between religious belief and students' acceptance of the teaching of sexuality education?

To what extent will the predominant views among adolescents on the issue of sex influence the acceptance of the teaching of sexuality education?

Table 1. Students Perception of the teaching of Sex Education

\begin{tabular}{|c|c|c|c|c|c|}
\hline & Students Perception of Sex Education & SA & $\mathbf{A}$ & $\mathbf{D}$ & SD \\
\hline $\bar{a}$ & Sex education is for the married & $\begin{array}{c}63 \\
52.5 \%\end{array}$ & $\begin{array}{c}36 \\
30 \%\end{array}$ & $\begin{array}{c}14 \\
11.7 \%\end{array}$ & $\begin{array}{c}7 \\
5.8 \%\end{array}$ \\
\hline $\mathrm{b}$ & $\begin{array}{l}\text { Sex education is all about teaching young people how to use } \\
\text { condoms in order to avoid unwanted pregnancy. }\end{array}$ & $\begin{array}{l}38 \\
31.7 \%\end{array}$ & $\begin{array}{c}29 \\
24.2 \%\end{array}$ & $\begin{array}{c}32 \\
26.7 \%\end{array}$ & $\begin{array}{c}21 \\
17.4 \%\end{array}$ \\
\hline c & $\begin{array}{l}\text { Sex education is all about teaching young people to abstain } \\
\text { from sex till marriage }\end{array}$ & $\begin{array}{c}57 \\
47.5 \%\end{array}$ & $\begin{array}{c}27 \\
22.5 \%\end{array}$ & $\begin{array}{c}17 \\
14.2 \%\end{array}$ & $\begin{array}{c}19 \\
15.8 \%\end{array}$ \\
\hline $\mathrm{d}$ & I am too young for sex education & $\begin{array}{c}45 \\
37.5 \%\end{array}$ & $\begin{array}{c}31 \\
25.8 \%\end{array}$ & $\begin{array}{c}26 \\
21.7 \%\end{array}$ & $\begin{array}{c}18 \\
15 \%\end{array}$ \\
\hline $\mathrm{e}$ & $\begin{array}{c}\text { Sex education corrupts the minds of young people } \\
\text { Average Percentage of Responses }\end{array}$ & $\begin{array}{l}37 \\
30.8 \% \\
48\end{array}$ & $\begin{array}{l}34 \\
28.3 \% \\
31.4\end{array}$ & $\begin{array}{l}29 \\
24.2 \% \\
23.6\end{array}$ & $\begin{array}{l}20 \\
16.7 \% \\
17\end{array}$ \\
\hline
\end{tabular}

Source: Fieldwork - November, 2017 
In Table 1 above, it was observed that 63 (52\%) of respondents' strongly agreed that sex education is for the married, thus, showing their ignorance of the purpose of school-based sex education. Adolescents in schools are the main target of school based-sex education. It was also observed in Table 1 above that students possess the erroneous perception that sex education is all about teaching young people how to use condoms in order to avoid unwanted pregnancy and prevent sexually transmitted diseases as 38 (32\%) strongly agreed. Also, 57 (47.7\%) strongly agreed that sex education is all about teaching young people to abstain from sex till marriage. Abstinence is a very important purpose/goal of school-based sex education but that is not all it is to sex education. According to Sex Information Education Council of the United States (SIECUS, 2004) sex education is a lifelong process of acquiring information and forming attitudes, beliefs, and values. It encompasses sexual development, sexual and reproductive health, interpersonal relationships, affection, intimacy, body image, and gender role. The above responses to the items show that students have poor knowledge of sex education.

In Table 2, some of the content of sex education taught in school was stated as item statements for respondents to indicate their agreement or disagreement to them in order to ascertain the extent of their influence on students' perception of sexuality education. The result is presented on Table 2 .

In terms of the influence of sex education content taught in school, the most influential as examined in this study is the teaching of the reproductive organs which ranked highest, followed by the teaching on sexual abuse and rape issues. The least is the teaching of HIV and STD to help understand the consequences of engaging in sex.

Table 2. Influence of the Content of Sex Education on Students' Perceptions of Sexuality Education

\begin{tabular}{|c|c|c|c|c|c|c|c|}
\hline & Content of Sex Education & $\mathbf{S A}$ & $\mathbf{A}$ & $\mathbf{D}$ & SD & $\mathrm{X}=\mathrm{EfX} / \mathrm{Ef}$ & Rank \\
\hline $\mathrm{a}$ & $\begin{array}{l}\text { The teaching of puberty and sexual } \\
\text { development will help me better } \\
\text { understand the changes in my body. }\end{array}$ & $\begin{array}{c}61 \\
50.8 \%\end{array}$ & $\begin{array}{c}41 \\
34.2 \%\end{array}$ & $\begin{array}{c}13 \\
10.8 \%\end{array}$ & $\begin{array}{c}5 \\
4.2 \%\end{array}$ & 3.32 & $4^{\text {th }}$ \\
\hline $\mathrm{b}$ & $\begin{array}{c}\text { The teaching of HIV/AIDS and STDs helps } \\
\text { me understand the consequences of } \\
\text { engaging in sex. }\end{array}$ & $\begin{array}{c}67 \\
55.8 \%\end{array}$ & $\begin{array}{c}30 \\
25 \%\end{array}$ & $\begin{array}{c}15 \\
12.5 \%\end{array}$ & $\begin{array}{c}8 \\
6.7 \%\end{array}$ & 3.30 & $5^{\text {th }}$ \\
\hline c & $\begin{array}{l}\text { I do not feel comfortable when the male } \\
\text { and female reproductive systems and } \\
\text { organs are being taught in the class. }\end{array}$ & $\begin{array}{c}78 \\
65 \%\end{array}$ & $\begin{array}{c}22 \\
18.3 \%\end{array}$ & $\begin{array}{c}11 \\
9.2 \%\end{array}$ & $\begin{array}{c}9 \\
7.5 \%\end{array}$ & 3.78 & $1^{\text {st }}$ \\
\hline $\mathrm{d}$ & $\begin{array}{l}\text { I don't think teaching students' } \\
\text { contraceptive methods like use of condoms } \\
\text { and pills in pregnancy prevention is } \\
\text { necessary. }\end{array}$ & $\begin{array}{c}57 \\
47.5 \%\end{array}$ & $\begin{array}{c}46 \\
38.3 \%\end{array}$ & $\begin{array}{c}16 \\
13.3 \%\end{array}$ & $\begin{array}{c}1 \\
0.9 \%\end{array}$ & 3.33 & $3^{\text {rd }}$ \\
\hline $\mathrm{e}$ & $\begin{array}{c}\text { The teaching of sexual abuse and rape } \\
\text { issues will help adolescents better protect } \\
\text { themselves. }\end{array}$ & $\begin{array}{c}75 \\
62.5 \%\end{array}$ & $\begin{array}{c}38 \\
31.7 \%\end{array}$ & $\begin{array}{c}4 \\
3.3 \%\end{array}$ & $\begin{array}{c}3 \\
2.5 \%\end{array}$ & 3.54 & $2^{\text {nd }}$ \\
\hline
\end{tabular}

Table 3 examines the variables that could influence students' perception of sex education and the results are presented in Table 3.

In Table 3: It was observed that 75 (62.5\%) agreed to the fact that parental upbringing is a variable that may influence sex education. This implies that parents have a huge role to play in sex education. Also, 57 (47.5\%) respondents strongly agreed that religious belief is a variable that may influence sex education and $16(13.3 \%)$ disagreed to that fact. In terms of the extent of the variables influence, item mean was used to rank the variables to ascertain their influence. 
It was found that peer pressure had the greatest influence among the possible variables that can influence adolescent perception of sex education, followed by parental upbringing then religious belief ranked third. 67 (55.8\%) strongly agreed and 42 (35\%) disagreed that prevailing secular music and videos influences students acceptance of sex education. This shows that the students' awareness of the impact of mainstream popular music and videos on their perception of sex issues is divided.

Table 3. Variables that may Influence Students' Perceptions of Sex Education

\begin{tabular}{|c|c|c|c|c|c|c|c|}
\hline $\mathbf{S} / \mathbf{N}$ & $\begin{array}{c}\text { Variables that may influence } \\
\text { sex education }\end{array}$ & SA & $\bar{A}$ & $\bar{D}$ & SD & $\begin{array}{c}X= \\
\text { EfX/Ef }\end{array}$ & Rank \\
\hline $\bar{a}$ & Social media & $\begin{array}{c}61 \\
50.8 \%\end{array}$ & $\begin{array}{c}41 \\
34.2 \%\end{array}$ & $\begin{array}{c}13 \\
10.8 \%\end{array}$ & $\begin{array}{c}5 \\
4.2 \%\end{array}$ & 3.32 & $4^{\text {th }}$ \\
\hline $\mathrm{b}$ & $\begin{array}{c}\text { Current secular music and } \\
\text { videos }\end{array}$ & $\begin{array}{c}67 \\
55.8 \%\end{array}$ & $\begin{array}{c}30 \\
25 \%\end{array}$ & $\begin{array}{c}15 \\
12.5 \%\end{array}$ & $\begin{array}{c}8 \\
6.7 \%\end{array}$ & 3.30 & $5^{\text {th }}$ \\
\hline c & Peer pressure & $\begin{array}{c}78 \\
65 \%\end{array}$ & $\begin{array}{c}22 \\
18.3 \%\end{array}$ & $\begin{array}{c}11 \\
9.2 \%\end{array}$ & $\begin{array}{c}9 \\
7.5 \%\end{array}$ & 3.78 & $1^{\text {st }}$ \\
\hline$d$ & Religious beliefs of the people & $\begin{array}{c}57 \\
47.5 \%\end{array}$ & $\begin{array}{c}46 \\
38.3 \%\end{array}$ & $\begin{array}{c}16 \\
13.3 \%\end{array}$ & $\begin{array}{c}1 \\
0.9 \%\end{array}$ & 3.33 & $3^{\text {rd }}$ \\
\hline $\mathrm{e}$ & Parental upbringing & $\begin{array}{c}75 \\
62.5 \%\end{array}$ & $\begin{array}{c}38 \\
31.7 \%\end{array}$ & $\begin{array}{c}4 \\
3.3 \%\end{array}$ & $\begin{array}{c}3 \\
2.5 \%\end{array}$ & 3.54 & $2^{\text {nd }}$ \\
\hline $\mathrm{f}$ & School social environment & $\begin{array}{c}43 \\
35.8 \%\end{array}$ & $\begin{array}{c}57 \\
47.5 \%\end{array}$ & $\begin{array}{c}5 \\
4.2 \%\end{array}$ & $\begin{array}{c}15 \\
12.5 \%\end{array}$ & 3.07 & $7^{\text {th }}$ \\
\hline g & Culture & $\begin{array}{c}65 \\
54.2 \%\end{array}$ & $\begin{array}{c}35 \\
29.2 \%\end{array}$ & $\begin{array}{c}9 \\
7.5 \%\end{array}$ & $\begin{array}{c}11 \\
9.1 \%\end{array}$ & 3.28 & $6^{\text {th }}$ \\
\hline
\end{tabular}

Source: Fieldwork - November, 2017

Table 4. Teacher's gender influence on sex education

\begin{tabular}{|c|c|c|c|c|c|}
\hline & Teacher's Gender & SA & $\mathbf{A}$ & D & SD \\
\hline $\bar{a}$ & $\begin{array}{l}\text { I will feel uncomfortable if a male teacher should } \\
\text { describe the female reproductive system in class. }\end{array}$ & $\begin{array}{c}63 \\
52.5 \%\end{array}$ & $\begin{array}{c}25 \\
20.8 \%\end{array}$ & $\begin{array}{c}24 \\
20.0 \%\end{array}$ & $\begin{array}{c}8 \\
6.7 \%\end{array}$ \\
\hline $\mathrm{b}$ & $\begin{array}{l}\text { It does matter if a female teacher should describe the } \\
\text { male reproductive system }\end{array}$ & $\begin{array}{c}38 \\
31.7 \%\end{array}$ & $\begin{array}{c}19 \\
15.8 \%\end{array}$ & $\begin{array}{l}2 \\
1.7 \%\end{array}$ & $\begin{array}{c}61 \\
50.8 \%\end{array}$ \\
\hline $\mathrm{c}$ & $\begin{array}{l}\text { Having a sex educator of the opposite sex will affect } \\
\text { my emotions negatively. }\end{array}$ & $\begin{array}{c}57 \\
47.5 \%\end{array}$ & $\begin{array}{c}27 \\
22.5 \%\end{array}$ & $\begin{array}{c}17 \\
14.2 \%\end{array}$ & $\begin{array}{c}19 \\
15.8 \%\end{array}$ \\
\hline $\mathrm{d}$ & $\begin{array}{l}\text { I cannot be comfortable discussing sex issues with a } \\
\text { teacher of the opposite sex. }\end{array}$ & $\begin{array}{c}45 \\
37.5 \%\end{array}$ & $\begin{array}{c}31 \\
25.8 \%\end{array}$ & $\begin{array}{c}26 \\
21.7 \%\end{array}$ & $\begin{array}{c}18 \\
15.0 \%\end{array}$ \\
\hline $\mathrm{e}$ & $\begin{array}{l}\text { I think male teachers should teach male sex } \\
\text { education while female teachers should teach female } \\
\text { students sex education. }\end{array}$ & $\begin{array}{c}49 \\
40.8 \%\end{array}$ & $\begin{array}{c}44 \\
36.7 \%\end{array}$ & $\begin{array}{c}7 \\
5.8 \%\end{array}$ & $\begin{array}{l}20 \\
16.7 \%\end{array}$ \\
\hline & Average Percentage of Responses & 39 & 29.2 & 15.2 & 25.2 \\
\hline
\end{tabular}

Research question two seek to find out if teacher's gender influences students' attitude to the teaching of sexuality education and the result is presented in Table 4.

It was found out that 84 out of the 120 respondents indicated that having a sex educator of the opposite sex will affect their emotions negatively and 93 respondents think that a male teacher should teach male students sex education and female teacher should teach female students.

Research question three was on relationship between religious belief and students' acceptance of the teaching of sexuality education and a null hypothesis of: there is no significant difference in the religious views of students on sexuality education was tested using chi-square at $\mathrm{p}>0.05$ and result presented on Table $5 \mathrm{~b}$. 
Table 5. Religious Views of Students on Sexuality Education

\begin{tabular}{|c|c|c|c|c|c|}
\hline & Religious Views of Students on Sexuality Education & SA & $\mathbf{A}$ & D & SD \\
\hline $\mathrm{a}$ & $\begin{array}{c}\text { Participating in a sex education class is against my } \\
\text { religious belief }\end{array}$ & $\begin{array}{c}56 \\
46.7 \%\end{array}$ & $\begin{array}{c}38 \\
31.7 \%\end{array}$ & $\begin{array}{c}17 \\
14.2 \%\end{array}$ & $\begin{array}{c}9 \\
7.4 \%\end{array}$ \\
\hline $\mathrm{b}$ & $\begin{array}{l}\text { My religious belief promotes abstinence only as the } \\
\text { right sexual behaviour before marriage }\end{array}$ & $\begin{array}{c}67 \\
55.8 \%\end{array}$ & $\begin{array}{c}3 \\
2.5 \%\end{array}$ & $\begin{array}{c}8 \\
6.7 \%\end{array}$ & $\begin{array}{c}42 \\
35 \%\end{array}$ \\
\hline $\mathrm{c}$ & $\begin{array}{l}\text { My religion does not encourage the use of condoms in } \\
\text { pregnancy prevention so I cannot use one if I have it }\end{array}$ & $\begin{array}{c}75 \\
62.5 \%\end{array}$ & $\begin{array}{c}27 \\
22.5 \%\end{array}$ & $\begin{array}{c}14 \\
11.7 \%\end{array}$ & $\begin{array}{c}4 \\
3.3 \%\end{array}$ \\
\hline $\mathrm{d}$ & I will feel sinful attending a sex education class & $\begin{array}{c}60 \\
50 \%\end{array}$ & $\begin{array}{c}36 \\
30 \%\end{array}$ & $\begin{array}{c}19 \\
15.8 \%\end{array}$ & $\begin{array}{c}5 \\
4.2 \%\end{array}$ \\
\hline $\mathrm{e}$ & I worry that sex education will corrupt my mind & $\begin{array}{c}57 \\
47.5 \%\end{array}$ & $\begin{array}{c}46 \\
38.3 \%\end{array}$ & $\begin{array}{c}14 \\
11.7 \%\end{array}$ & $\begin{array}{c}3 \\
2.5 \%\end{array}$ \\
\hline
\end{tabular}

Source: Fieldwork - November, 2017

In Table 5 above, only three respondents strongly disagree that they worry that sex education will corrupt their mind, a greater number (103) agreed that they worry that sex education will corrupt their minds. There are a lot of errors in adolescents' perception of sex education and religion is not helping.

Table $5 \mathbf{b}$. Chi-square testing of responses on religious views of students

\begin{tabular}{ccc}
\hline & Observed & Expected \\
\hline Strongly Agreed & 52.2 & 30 \\
Agreed & 30 & 30 \\
Disagreed & 14.4 & 30 \\
Strongly Disagreed & 12.6 & 30 \\
\hline
\end{tabular}

$$
\begin{gathered}
X^{2}=\left(\frac{O-E)^{2}}{E}\right. \\
\left.\left.X^{2}=\frac{(52.2-30}{30}\right)^{2}+\frac{(30-30)^{2}}{30}+\frac{(14.4-30}{30}\right)^{2}+\frac{(12.6-30)^{2}}{30} \\
X^{2}=7.156
\end{gathered}
$$

With degree of freedom 3 under 0.05 probability level, the chi-square calculated is 7.156 and the critical value is 7.815 meaning that the calculated value is less than the critical value and as such the null hypothesis of there is no significant difference in the respondents' religious views on sex education is accepted.

Research question four is on the predominant views among adolescents on the issues of sexuality education and the result is presented on Table 6 .

From Table 6 above, the predominant views of students on sex education was their agreement that abstinence from premarital sex will make them feel less of their peers who engage in sexual activities. $72(62+10)$ of the respondents agreed to the item statement while 102 out of the 120 respondents disagreed with the item statement that they cannot contract HIV/AIDs even if they engage in sex; meaning they understand that they can contract HIV through sexual intercourse. When the influence of these predominant views were ranked using item mean, the highest rank was on the item statement of 'I cannot contract HIV/AIDs even if I engage in sex' and the second highest was on 'I believe that abstaining from sex will affect one's health later in life. During the focus group interaction, the respondents were asked if the envisaged effect on health later in life was going to be a negative or positive effect; and they all echoed 'negative effect'. Little wonder the high rate 
of teen promiscuity. Such erroneous views could be detrimental to health. The focus group discussion which was based on the interview schedule developed by the researcher was actually used to triangular the findings from the questionnaire and further probe some of the statement items in the questionnaire that needed further clarifications.

Table 6. Predominant Views of Adolescents on Issues of Sex Education

\begin{tabular}{|c|c|c|c|c|c|c|c|}
\hline & $\begin{array}{l}\text { Influence of predominant view sex } \\
\text { education }\end{array}$ & SA & A & D & SD & $\begin{array}{c}X= \\
\sum F X / \sum F\end{array}$ & Rank \\
\hline 1 & $\begin{array}{l}\text { I believe that abstaining from sex will } \\
\text { affect one's health later in life }\end{array}$ & $\begin{array}{c}45 \\
37.5 \%\end{array}$ & $\begin{array}{c}28 \\
23.3 \%\end{array}$ & $\begin{array}{c}42 \\
35 \%\end{array}$ & $\begin{array}{c}5 \\
4.2 \%\end{array}$ & 2.94 & $2^{\text {nd }}$ \\
\hline 2 & $\begin{array}{c}\text { Abstaining from premarital sex makes } \\
\text { you feel less of your peers }\end{array}$ & $\begin{array}{c}62 \\
51.7 \%\end{array}$ & $\begin{array}{c}10 \\
8.3 \%\end{array}$ & $\begin{array}{c}22 \\
18.3 \%\end{array}$ & $\begin{array}{c}26 \\
21.7 \%\end{array}$ & 2.90 & $4^{\text {th }}$ \\
\hline 3 & $\begin{array}{l}\text { A girl cannot get pregnant in her first } \\
\text { sexual encounter }\end{array}$ & $\begin{array}{c}33 \\
27.5 \%\end{array}$ & $\begin{array}{c}32 \\
26.7 \%\end{array}$ & $\begin{array}{c}12 \\
10 \%\end{array}$ & $\begin{array}{c}43 \\
35.8 \%\end{array}$ & 2.54 & $5^{\text {th }}$ \\
\hline 4 & $\begin{array}{l}\text { It does not matter if one is a virgin or } \\
\text { not }\end{array}$ & $\begin{array}{c}9 \\
7.5 \%\end{array}$ & $\begin{array}{c}28 \\
23.3 \%\end{array}$ & $\begin{array}{c}45 \\
37.5 \%\end{array}$ & $\begin{array}{c}38 \\
31.7 \%\end{array}$ & 2.93 & $3^{\text {rd }}$ \\
\hline 5 & $\begin{array}{c}\text { I cannot contract HIV/AIDs even if I } \\
\text { engage in sex }\end{array}$ & $\begin{array}{c}0 \\
0 \%\end{array}$ & $\begin{array}{c}8 \\
6.7 \%\end{array}$ & $\begin{array}{c}62 \\
51.7 \%\end{array}$ & $\begin{array}{c}50 \\
41.6 \%\end{array}$ & 3.35 & $1^{\text {st }}$ \\
\hline
\end{tabular}

\section{Discussion of Findings}

Analysis of data collected from the field revealed that students held the view that sex education is all about teaching young people to use condoms in order to prevent pregnancy and sexually transmitted diseases. According to (Tanton et al., 2015), many effective sex education programmes incorporate lessons on using condoms into their efforts to reduce young people's risk of unplanned pregnancy and sexually transmitted diseases.

Analysis of data collected from the field revealed that students also held the view that sex education is all about teaching young people to abstain from sex till marriage. A good sex education is not only about preaching abstinence but it is about providing comprehensive and accurate knowledge to adolescent that will enable them to make informed choices this findings collaborated with (West, 2012) who examined the perception of sex education among secondary school students in Port-Harcourt - the capital city of one of the States in the South-South Geo-Political Zone of Nigeria. A structured, anonymous and selfadministered questionnaire used as instrument for data collection was distributed amongst a convenient sample of 1050 secondary school students attending a series of school debate in Port-Harcourt Metropolis. Results indicated that secondary school students are aware of the subject of sex education, but lack adequate information on sexuality issues. (West. 2012) study recommended amongst others that parents, teachers and students need to be enlightened on sex education. Furthermore, it also recommended that there is a need to inculcate sex education into the school curriculum. The findings also collaborated with (Kingsley et al., 2014) findings in Ghana on parental attitude towards sex education.

Analysis of data collected for this study also shows that parental upbringing is a variable that may influence students perception and acceptance of sex education which is in accordance with (Kohler et al., 2008) who noted that parents are the most important educators of their children in these matters, and hence they should be held responsible if this duty to their children is neglected. It therefore, requires them (the parents) to make concerted efforts to be good examples, to listen to their children, to give them their time and to show that they can trust them. Today, many school children and even more have continued to suffer from the deprivation of necessary sex education and or insufficient sex 
education from their parents. One reason may be that parents often shy away from issues of this nature or are inadequate in giving their children education on sex issues. Some parents would refrain from talking about sex with their children as it is believed to pollute their minds. They may believe it is safer that children grow up to learn and discover such information. But, this is not always the case as young people have been found to discover such 'sacred knowledge' much earlier than expected (Teferra et al., 2015).

The teaching of sex education increased understanding and hence attitudinal change towards sexuality issues examined in the questionnaire. Findings from the study also revealed that most male participants feel more comfortable in learning sex education if the teacher is same gender and the same thing goes for the female participants. Sex education should be taught to female students by same gender teacher and vice versa.

All the participants happened to be Christians and indicated that their religion plays a vital role in how they view and accept what is taught in sex education in school which is mostly abstinence as the key to avoidance of sexually transmitted diseases. Some of the erroneous perception revealed in this study colloborated with (Nwaorgu, 2008) findings. (Nwaorgu, 2008) assessed reproductive health knowledge and practices among Junior Secondary School Grade one students in Enugu Stat - one of the States in the South East Geo-Political Zones of Nigeria. The study was a cross-sectional survey of the reproductive health knowledge and practices of 412 Junior Secondary School pupils from 12 schools in Enugu State. The instrument was a uniform set of structured self-administered questionnaires. Results from the study revealed that about $50.9 \%$ of the respondents hold the belief that a girl would not get pregnant in her first sexual encounter and $50 \%$ of the participants reported that they have had sex, at the age less than 11 years when they must have been in the primary school.

\section{Conclusion}

The study provided feedback on how students think and feel about sexuality education. Sexuality is a central aspect of being human. It encompasses gender, sex, identity and roles, pleasure, egotism, intimacy and reproduction. Sexuality is not only experienced physically but expressed in thought, desires, belief, fantasy, values, attitudes, behaviours, practices, roles and relationship.

Secondly, condom education in sex education must be carefully handled as it may increase tendency for condom use among as well mar students perception of sex education. Consequently, the researcher is of the view that condom use in sex education should be deemphasized and emphasizes placed on abstinence. Thirdly, the impact of the prevailing language and content of mainstream popular and secular music and videos on sex education cannot be overlooked. Government must actively control, regulate and supervise the language and content of secular music and videos to avoid sending wrong messages to adolescents and heightening their emotions negatively.

\section{Scientific Significance}

The provision of adequate and comprehensive sexuality education has become increasingly important and necessary in modern times where the standards or norms surrounding sexual relationships have been almost obliterated by increasing modernization and a sexually-charged media atmosphere. Recent controversial issues on human sexuality such 
as gay rights, same sex marriage, trans-gender, sexual orientation, etc have only succeeded in creating more confusion for young individuals as to what is the right sexual behavior. The responsibility, therefore, lies on parents, teachers, counselors and educators to provide the needed sex education for the moral guidance of adolescents.

\section{Recommendations}

There is need for teachers to properly educate or inform students of the reason for the teaching of sex education in schools so as to eliminate wrong perceptions and or attitudes towards the subject.

The relevant government agencies in education must ensure that only professionally trained teachers are deployed in the classrooms to teach sex education so that its purpose will not be defeated.

There is the need for the Ministry of education in conjunction with other stakeholders to constantly review the existing sex education curriculum so that it can be more relevant to students in a fast-changing society.

Government must control the content and language of mainstream secular music and videos as its impact on students perception of sex and sex issues is enormous and cannot be undermined.

\section{References}

Akande, AA, Akande, TM. (2007). Knowledge and perception of sexuality education among students of a rural secondary school in Kwara State, Nigeria, Nigerian Med Practit, 52(3):5559.

Akpama, EG. (2013). Parental perception of the teaching of sex education to adolescent in secondary school in Cross River State, Nigeria, J Res Method Educat, 1(3):31-36.

Barret, MA. (2010). Trend in teen pregnancy rate from 1996 - 2006: A study comprising of Canada, Sweden, USA and England / Wales, Canadian Journal of Human Sexuality, 2010.

Fentahun, N, Assefa, T, Alemeseged, F, Ambaw, F. (2012). Parents' perception, students' and Teachers' attitude towards school sex education, Ethiopian J Heal Sci, 22(2):99-106.

Kingsley, N, Kobina, IA, Maxwell, A, Andrew, LD. (2014). Parental attitude towards sex education at the lower primary in Ghana, Int J Elemen Educat, 3(2):21-29.

Kohler, PK, Manhart, LE, Lafferty, WE. (2008). "Abstinence-Only and Comprehensive Sex Education and the Initiation of Sexual Activity and Teen Pregnancy". J Adol Heal, 42(4):344351. doi: 10.1016/j.jadohealth.2007.08.026.

Nwaorgu, IJ. (2008). Reproductive health knowledge and practice among Junior Secondary School Grade one. Nigerian J Heal Educat, 13(1):6-10

SIECUS (2004) state profile; A portrait of sexuality education and abstinence only marriage programs in the United State, New York.

Tanton, C, Jones, W, Macdowell, S, Clifton, KR, Mitchell, J, Datta, R, Lewis, R, Field, N, Sonnenberg, P, Stevens, A, Wellings, K, Johnson, AM, Mercer, CH. (2015). Pattern and Trends 
in sources of information about sex among young people in Britain: evidence from three National surveys of sexual attitudes and lifestyles, Biomed J Open, 5:e007834, available at: http://bmjopen.bmj.com

Teferra, TB, Erena, AN, Kebede, A. (2015). Prevalence of sexual practice and associated factors among undergraduate health science students of Madawalabu University, Bale Goba, South East Ethiopia. Pan Afr Med J, ISSN 1937-8686 doi: 10.11604/pamj.2015.20.209.4525, pmcid: pmc447011

West, A. (2012). Perception of sex education among secondary school students in Port Harcourt, Rivers State, Nigeria, Nigerian School Health Journal, 22(1):12-18.

How to cite this article: Joy-Telu Hamilton-Ekeke*, Assessing Students' Perception Towards the Teaching of Sexuality Education in Senior Secondary Schools in Nigeria. International Journal of Advanced Biological and Biomedical Research, 2019, 7(3), 204-212. Link: http://www.ijabbr.com/article 34663.html 